\title{
Between Myth and Oblivion: A Biography of Ákos Domanovszky
}

\section{Mauro Guerrini PhD}

To cite this article: Mauro Guerrini PhD (2001) Between Myth and Oblivion: A Biography of Ákos Domanovszky, Cataloging \& Classification Quarterly, 32:3, 57-72, DOI: 10.1300/ J104v32n03_05

To link to this article: http://dx.doi.org/10.1300/J104v32n03_05

Published online: 24 Oct 2008.

Submit your article to this journal $\square$

Џ Article views: 20

Q View related articles ๘ 


\title{
Between Myth and Oblivion: A Biography of Ákos Domanovszky
}

\author{
Mauro Guerrini
}

\begin{abstract}
The life and career of Ákos Domanovszky, Hungarian librarian and scholar of library science, is almost unknown even in his own country, apart from an inner circle of scholars who consider his studies on library catalogue functions an essential contribution to cataloguing theory. He was a major participant in the ICCP (Paris, 1961) and the IMCE (Copenhagen, 1969); and the author of the Hungarian draft cataloguing code, adopted as a national standard in 1972. He published several important essays in national and international journals such as Libri, but his crowning achievement as a scholar was Functions and Objects of Author and Title Cataloguing (1974), which is discussed and analysed in this paper.
\end{abstract}

KEYWORDS. Domanovszky, cataloging, ICCP, Hungarian cataloguing code, theory of cataloguing

These experiences led me to discover a fact of which most librarians are not aware. The catalogue of a large library, unless one takes daily care of its consistency and its efficiency, poses enormous problems for librarians. In other words, cataloguing is far from being as simple as one might believe.

Ákos Domanovszky

Mauro Guerrini, PhD, is Professor of Library Science, University of Rome La Sapienza, Via Vicenza 23, 00185-Roma, Italy (E-mail: M.guerrini@leonet.it).

The author wishes to thank Carlo Bianchini for his valuable help given in translation of the English text, and warm thanks to Michael Gorman who has edited the article.

Ákos Domanovszky, "Funzioni e oggetti della catalogazione per autore e titolo," Forum Editrice Universitaria Udinese, Udine 2001. Reprinted with permission. 


\section{INTRODUCTION}

Biographical information about Ákos Domanovszky, Hungarian librarian and library science scholar, is extremely meagre. No sketch of his life is available in library science or general encyclopaedias. ${ }^{1} \mathrm{He}$ is nearly unknown in his own country, still less in others, with the exception of a limited circle of scholars, who consider his studies on library catalogue functions to be a major contribution. ${ }^{2}$ Gabriella Rósza Pogányné is the only author to have written a biographical profile of him. Its title is "The librarian. His work will not be perfect if he will consider only rules and not the man they are written for. In memory of Ákos Domanovszky," in the December 1999 issue of "Könyv, könyvtár, könyvtáros."” Seventeen years after his death, Rósza Pogányné notes the almost complete oblivion of a scholar who had been a central character in his own country and in the international library community. Domanovszky made original contributions to cataloguing theory, took a major role in the ICCP (International Conference on Cataloguing Principles, Paris, October 1961) and in the IMCE (International Meeting of Cataloguing Experts, Copenhagen, August 1969), and was a leading figure in the drafting of Hungarian cataloguing code. He published articles in national and international reviews, such as Libri and, above all, published in 1974 Functions and Objects of Author and Title Cataloguing, the work that more than any other confirms his reputation as a master. ${ }^{4}$

\section{THE PROFESSION OF LIBRARIAN}

Ákos Domanovszky was born in Bratislava, on 28 October 1902 and died in Budapest on 9 April 1982; ${ }^{5}$ he was the first son of Sándor (1877-1955), a teacher in a Slovak school, and grandson of Endré (1817-1895), philosopher and writer, professor at Literature Faculty of Hungarian Scientific Academy of Law. In 1904 his family moved to Budapest, when Sándor Domanovsky became a teacher at the Trading Academy there; later he trained in the University Library, and eventually became professor and rector of University of Budapest. He was an historian and a member of the Hungarian, Austrian and Polish Academies of Science. Due to political reasons, from 1949 on, he was suspended from Hungarian Academy of Sciences, and reinstated only in 1989, thirty-four years after his death and after the end of the communist regime. Ákos had two brothers, Endré (1907-1974) and Geörgy (1909-1983). The former was a painter and teacher, from 1930 to 1945 at the Decorative Art School, then professor of clothing history at University of Budapest. The latter was an art historian and director of the Hungarian Ethnographical Museum, an expert in popular and decorative art, and the author of many works in Hungarian and in other languages.

Ákos, therefore, belonged to a family with an intellectual tradition. In compliance with a tradition dating back to the 16th and 17th centuries, such Hungarian families sent their youths to study and travel abroad-in effect to make a kind of 
cultural and professional pilgrimage, which, in the 20th century was undertaken mainly by scientists, artists and librarians. ${ }^{6}$ Endré, Sándor's father, attended lessons at the Halle University, Saxony for three years. Sándor went to the Hungarian Institute of History in Vienna many times. Endré, Ákos' brother, won a scholarship to study in Rome. Ákos, after attending high school, matriculated from the Law Faculty in Munich and returned to Budapest in 1925 to take a degree in Law. From 1924 to 1926 he worked, as an assistant professor, with Laszlo Budai and Farkas Heller at the Faculty of Economic Sciences in Budapest. He was associated for a short period with the Hungarian National Centre for Bibliography and the Publishing Trade; and, from 1926 to 1928, he trained at the University Library of Budapest-first as a library assistant, later as a librarian. He spent the following two years in Berlin, winning a scholarship to the Humbolt Economical and Library Science Institute. In 1935, he became librarian at Kiralyi Erzsebet Library of Pecs-first as vice-director, then as director-and completed a library reorganisation and reformation started by his predecessor József Fitz. His stay in Pécs lasted for seven years, up to 1942. During this period he conceived and worked toward the idea of creating a new catalogue based on the Hungarian code of 1924. In autumn of 1942 he was transferred to University Library of Budapest, first as a librarian and then, starting from 1945, as Head of Section. He should have been the director of the library, but that post was entrusted to Laszlo Matrai, an important librarian of that period-the president of the Hungarian Library Association and professor of philosophy at Budapest University. Domanovsky's work with Matrai further encouraged Domanovzsky in his scientific and professional efforts. Until his retirement in 1972, Ákos devoted himself to the revision and improvement of Hungarian library catalogues. He considered such an overhaul indispensable because he was aware those catalogues were designed and constructed according to antiquated concepts, models, and rules dating back to the 19th century. Domanovsky had a reserved character and scholarly demeanour.

\section{DOMANOVSKY'S THEORIES}

Studies that, in the first part of the century, led to elaboration of international cataloguing principles, encouraged Domanovszky in his work. He began with an Interlibrary Commission, which charged the Central National Library to draft cataloguing rules for Hungary. Later, as librarian at University Library of Budapest, he started a project to reform that library's cataloguing methodology. This project was divided into three steps. The first started in 1949 and consisted of introducing the Universal Decimal Classification-the first time it was to be used in Hungary-and in building a subject catalogue. Domanovszky stated that the simultaneous building of two analytical catalogues showed how our perception was correct. It made clear how far our cataloguing system deficiencies had paralysed library work. ${ }^{7}$ The second step began in 1953, and consisted of the adoption of rel- 
ative call numbers, which made books easier to easier to locate and retrieve. Domanovszky observed that in this case too, they adopted the most rigid and mechanical version, which links each number to an unique item and he believed that the solution assured many advantages: simplicity in management, safety in check and no errors. In other words, it represented the most logical variant of the practice of using progressive numbers. The third step started in 1957 and concerned the integration of various catalogues and locations into a general author-title catalogue. This was a very important change that raised both the library and the staff to a higher more professional level. This was an integrated catalogue with entries for every kind of item. At the same time, the library was planning the creation of a classified catalogue of all its holdings. Domanovszky stated that the Great Wall of China, which till that moment divided rare books and serials from current bibliographic holdings, had been destroyed. From that moment on, according to Domanovszky, cataloguing standards were applied to all materials (except for incunabula and manuscripts). This practice led to a catalogue without precedent in Hungary. In Domanovszky's opinion, it was a great step forward, not only because gave uniformity to cataloguing, but also because it was previously impossible for patrons to gain access to the holdings of the whole library. Domanovszky believed, with justification, that such a consistently structured cataloguing system allowed users to locate sought materials more easily.

Domanovsky's professional experience and philosophy led him to believe that libraries must have consistent rules for librarians and easy, 'user-friendly' rules for patrons, so as to fulfil the main task of the catalogue. He often stated that libraries must maintain a catalogue, founded on a theoretical basis, that is capable of answering users' needs clearly and without ambiguity. Conversely, an inconsistent catalogue would be inimical to users' interests.

Beginning in the 1950s, Domanovszky published papers on cataloguing theory in national and international specialised reviews and worked with important national institutions involved in cataloguing rules. In 1957 he became the president of the Hungarian Cataloguing Commission. In 1958 the Hungarian National Library published Cataloguing Rules for Libraries (Konyvtari cimleirasi szabalyok). ${ }^{8}$ Domanovszky was aware that his country needed to profit from international standardisation efforts and, thus, became a member of many organisations, including IFLA, in which he took part in the work of various committees. He represented Hungary in a number of international conferences. In 1959 he took part in a London preliminary meeting of the Paris cataloguing conference. He had a major role in the Paris conference $(\mathrm{ICCP}=$ International Conference on Cataloguing Principles, Paris, October 1961). In August 1969, he took part in the International Meeting of Cataloguing Experts (IMCE) in Copenhagen, held to draw up a standard for bibliographic description. Domanovszky worked with Michael Gorman and others on the preliminary standard draft Standard Bibliographic Description, later to become the ISBD. ${ }^{9}$ Because of Domanovszky's efforts, Hungary was one of the first countries 
to adopt that standard. Domanovszky's interest in library science and in cataloguing went on after his retirement, in 1972, from the University Library. He continued working assiduously on the drafting of the Hungarian cataloguing code and contributing to theoretical debate, which resulted, eventually, in the publication of his Functions and Objects of Author and Title Cataloguing in 1974.

\section{THE PARIS PRINCIPLES AND THE NEW HUNGARIAN CODE}

After the Paris Conference of 1961, Hungary needed to review its cataloguing rules of 1953 (which had replaced the former rules of 1924) to bring them in conformity with the Paris Principles. Domanovszky published a short but important article, The New Hungarian Draft Code and the Paris Statement of Principles in "International cataloguing," 10 in which he described the philosophy inspiring the Cataloguing Commission, of which he was president, in incorporating the Paris Principles. Domanovsky wrote:

The most outstanding feature of the planned Hungarian reform is, in my opinion, its decisive change over to a complete acceptance of that function of the catalogue which I should term the second; the function of collecting in one place all the information the catalogue contains about a particular work, or, more precisely, about all the editions of a work and its variants and of uniting, by so doing, all those editions and variants so as to form a single composite object of cataloguing (see Statement of Principles, section 2.2). [ . . . ]. Completely in accord with the Paris Principles, it [the new code] includes one rule establishing clearly and explicitly the compulsory use of uniform names in headings, and another allowing no less explicitly an optional use of uniform titles as headings. It also gives a separate rule prescribing that the choice of the actual or uniform title which is to follow the heading in author entries should be made in accordance with the practice followed in the treatment of works entered under title.

He believed that note 2 of Paris Principles ${ }^{11}$ was incompatible with the recommendations of the IMCE Working Group, which was drafting an international standard for bibliographic description (ISBD) and "that this incompatibility cannot be overcome except by a rather artificial expedient-by describing a uniform title which is different from the <title proper>" to be considered "an integral part of the heading and not as the first element of the description." He accepted sections 9.45 and 11.5 of Principles, relating to corporate bodies and to serials with name or title changed. Domanovszky wrote, "These sections obviously suggest the very serviceable fiction that a change of name or title extinguishes the previous identity of the corporate body or serial-a fiction the introduction of which I regard as the luckiest stroke in the Statement of Principles." The new Hungarian code "accepts quite unequivocally [... ] section 10.3, main entry under title of the collection, and it does so without admit- 
ting the exception stipulated in section 10.34." As far as corporate bodies are concerned, he wrote: "A rule which fixes the exact boundaries of the area within which entries with corporate headings are to be applied. No code has yet be drawn up which has solved this problem, or has even approximated a satisfactory solution. The Statement of Principles is not an exception: Sections 9.11 and 9.12 are no less obscure and admissive of diverse or even contradictory interpretations [ . . ] ] they are not less incapable of coping with a problem which the futile efforts of a century have now conclusively proved to be about as hopeless of solution as the squaring the circle." He stated, "all post-Paris codes deviate more or less radically, from section 9.1. So does the Hungarian draft. It adopts section 9.11 in essence, though not without some reservations; but it rejects section 9.12 altogether," which states, "The main entry for a work should be made under the name of a corporate body [ . . ] when the wording of the title or title-page, taken in conjunction with the nature of the work, clearly implies that the corporate body is collectively responsible for the content of the work." The Hungarian draft accepted entry under corporate bodies for some works of corporate authorship, but rejected entries chosen for formal reasons such as presentation on a title page. Note 7 clarifies what this means: "e.g., serials whose titles consist of a generic term (Bulletin, Transactions, etc.) preceded or followed by the name of a corporate body, and that include some account of the activities of the body." Domanovszky concluded his contribution as follows: "To sum up: the new Hungarian Draft Code is one of few post-Paris codes to show a really far-reaching readiness to adopt the Statement of Principles and, to that end, to give up existing national practices. [ ... ] Hungary will be entitled to place in the front rank of nations willing to follow the call for international co-operation in the sphere author-title cataloguing." Domanovszky's proposals contained in his The New Hungarian Draft Code and the Paris Statement of Principles became the basis of a national standard at the end of $1972 .{ }^{12}$

\section{FUNCTIONS AND OBJECTS OF AUTHOR AND TITLE CATALOGUING}

Domanovsky published Functions and Objects of Author and Title Cataloguing (Budapest: Akadémiai Kiadó) in 1974, an acute and detailed analysis of the functions and objects of the author-title catalogue, considered by him to be more complex and important than the subject or classified catalogue. Functions and Objects is an intellectual work, fascinating to read, written in a very personal, but sometimes redundant, language; with a conceptual and stylistic perspective not found in the writings of other library science scholars. Domanovszky wrote his work in English, with the co-operation of Briton Anthony Thompson, formerly the IFLA general secretary. In 1975, Verlag Documentation (later Saur) in Munich published Functions and Objects with the same typographical composition, changing only its title-page and cover. To this day, Functions and Objects is found only in English, and there are no known English or Hungarian manuscripts in the Univer- 
sity Library in Budapest, with the Domanovsky family, or in any other place. ${ }^{13}$ The first edition had a limited run and is very rare; the second edition too is rare, and has been out of print for some time.

Domanovszky published Functions and Objects of Author and Title Cataloguing on the basis of his experience of Paris (ICCP) and of Copenhagen (IMCE), and after his work on the revision of the Hungarian code. It is, therefore, very rich in content. It consists of a reflection on work already accomplished, and of a proposal for an advanced discussion of cataloguing questions. Functions and Objects is, thus, the outcome of a professional and theoretical journey, it results from a whole professional life devoted to developing a theory of cataloguing and to setting out the most efficient means to improve its efficiency as a tool to connect users and holdings. He wrote that cataloguing codes have given only generic, even superficial, explanations of what "cataloguing objects" actually are. Thus he considered it necessary to define this concept unambiguously, considering the large and ambiguous number of existing terms. He believed cataloguing to have as its objects works published autonomously (e.g., a novel in one volume, a multi-volume encyclopaedia, a booklet, a geographic map) and works that are component parts of a publication (e.g., an article published in a serial, a work in a miscellaneous volume); it is concerned with both serial and autonomous objects (e.g., a manuscript). Cataloguing is concerned with publications composed of an elemental object-a book, a physically detached item, with its own typographic and specific identity; or of a main elemental object (also called primary and secondary (added) objects) that is subordinate to primary objects, but are intellectually autonomous, such as single articles in a one-volume collection; or a tertiary object, such as an enclosure or supplement. Cataloguing, as Eva Verona stated in her Literary Unit versus Bibliographical Unit ${ }^{14}$ (cited many times by Domanovszky), is concerned with publication in its double essence: as a physical object or bibliographic unit, and as an intellectual object or literary unit. Domanovszky delineated three classes of cataloguing objects:

1. works;

2. materialisations (manifestation) of a particular work;

3. groups of all works with a common genesis, e.g., an author's oeuvre.

The author-title catalogue, in Domanovszky's opinion, must accomplish a third function, beside the two defined in Paris Principles $\S 2.2$, that is to assemble the complete production of an author. An author-title catalogue system, therefore, must consider three entities:

1. works;

2. materialisations (manifestation) of a specific work;

3. all materialisations of the works of a specific author. 


\section{THE THREE FUNCTIONS OF THE CATALOGUE}

The term "function" refers to the catalogue's need (or feature) to convey information about library holdings. Each catalogue organises bibliographic information by the marks (characteristics) and formal aspects of items in the library. The author-title catalogue, in particular, arranges information by giving the formal characteristics of the item, in order to distinguish it from other items. Objects about which the author-title catalogue conveys information may be ranked in two classes:

1. autonomous objects that get separate entries of their own in the catalogue, under headings derived from their own distinguishing marks;

2. subordinate objects that do not get separate entries of their own.

The first function is atomistic in its essence-its main task is to convey specific information (isolated data) on single, elemental objects considered individually. The second and third functions link those "isolated" informational units by headings derived from the immaterial, intellectual characteristics of their respective objects (works); and then arranges the resulting catalogue information into a pattern of organic, intellectually coherent groups. These two functions create new composite and ordered informational units-each of which, separately considered, refers to an elemental object of the first function. The new informational units refer to a new composite cataloguing object, devoted to the second and the third functions. This means that a single book is a detached, elemental object, but may be also a component part of one, often two, or even more composite objects belonging to one or both other functions. In other words, because of the triplicity of the cataloguing functions (or multiplicity of functions), each book can be turned into three different objects of cataloguing. The first function is concerned with conveying information about all main elemental objects (physically separate items) in terms of their material characteristics. The second and the third functions are concerned with providing for collocating information about any object entered in the catalogue, combining immaterial component parts in new composite units. To fulfil the first function, a cataloguer enters each book in its own phisical marks (in its own terms)-under those tags (words), as author writes, attached to title-page, ${ }^{15}$ and more exactly under the marks (words) which refer to author or which represent the title. Both the first function and the second and the third have a twofold nature: physical and immaterial (intellectual). These aspects are not of equal importance, because their importance depends on catalogue functions. To fulfill the first function, the material aspect of the object catalogued is more important as a particular content is associated to a definite form. At the same time catalogue users are concerned with the intellectual characteristics of the objects (works) they seek. Therefore, a cataloguer's duty is to let each book be retrievable by means of: 
a. its physical marks (characteristics) (to fulfil the first function);

b. normalised headings derived from the work of which the physical publication is a manifestation (to fulfil the second and the third functions): its uniform marks, in its capacity of component part of the objects of the second and third functions.

This implies a correlation between:

a. the physical marks (characteristics) and elemental objects of the first function;

b. the uniform marks (headings) and composite objects of the second and the third functions.

Physical marks (characteristics) are needed to enter elemental objects, uniform marks (headings) to enter composite objects. There is no doubt about the proper object for main entries-always a primary elemental object. References too, as entry substitutes, provide for added headings both for their own objects and for composite objects of main and added entries.

\section{SECONDARY, TERTIARY AND CO-ORDINATED ADDED ENTRIES}

Domanovszky dedicated a large part of his work to added entries, and identified two main classes: co-ordinate added entries, and secondary and tertiary added entries. Co-ordinate added entries are equal in function, efficiency and importance to main entries, with which they are associated. These entries are needed to provide for primary elemental objects (e.g., editions with two or three authors, work of corporate bodies, anonymous works with different titles), under their formal marks (or appropriate normalised headings). Those marks (headings) can differ slightly in their capacity to identify and to locate the object (e.g., an author in the first position on a title-page bearing three authors may be more identifying than the second or the third author).

Secondary and tertiary added entries have non-primary works for their object. These entries are extensions of the first function, as far as they indicate elemental objects (books and other manifestations), secondary (works published in a miscellaneous volume and secondary contributions) and tertiary (minor contributions of persons or corporate bodies to works or to their editions). Secondary added entries are concerned with objects (works) incorporated in collections of intellectually separate and autonomous documents. Such documents, in their turn, comprise the contents of primary elemental objects and contents subordinate to those contents (such as appendices, introductions, forewords, epilogues, comments, when their authors differ from the author of the primary elemental object). They grant an added entry to object of main entries and record a component part of that object by an entry which is headed to the uniform mark proper of the component part. Tertiary added entries do not represent works as such. They embody a personal or collective intellectual con- 
tribution to the production of a work. Examples include: entries under the name of a translator or editor of a primary or secondary work entered under an author's personal name; entries under the names of corporate bodies playing a subordinate role, even if intellectually relevant, in the production of a primary or secondary elemental object in its turn indexed by a main or added entry under title, or under a more important corporate body, or under an author's personal name.

Secondary and tertiary added entries convey information about the works to which they apply and, thus, increase the efficiency of the catalogue. They offer supplementary access to primary elemental objects and introduce new elemental objects into the catalogue, enlarging the number of composite objects of the second and third functions.

\section{WORK AND EDITION IN THE FIRST, SECOND, AND THIRD FUNCTIONS}

We could summarise the tasks of the functions as follows.

I. The first function conveys information about all primary elemental objects (i.e., physically separate items). This function has a complementary effect which consists of conveying information about:

1. secondary elemental objects, i.e.,

1.1. intellectually separate and autonomous components of primary elemental objects (e.g., each paper contained in conference proceedings);

1.2. subordinate components of primary elemental objects (e.g., appendices, forewords, epilogues, comments, illustrations, photographs, whose author is not identifiable with author's name under which respective primary object is indexed);

2. tertiary elemental objects, i.e.,

2.1. specific aspects of primary or secondary objects (for instance, a translator's, editor's, curator's, reviser's contribution, when they differ from main author, or a minor contribution of a corporate body to the production of a primary or secondary elemental object).

II. The second function collocates information about each edition of each work available in the library, by linking information concerning each edition of a work, so as to create a new composite catalogue unit. This involves two concepts: the former material (each separate object of the second function is the sum of a fixed number of separate, or physically discrete, elemental objects-sets of books or parts of books all containing the same work); the latter immaterial (the object of the second function is an intellectual unit: the work itself). In the second function the material aspect is subordinate to the intellectual one. The latter defines how to 
select elemental objects to achieve the specific object of this function: The book does not consist of three different things, but it reveals itself in three different ways. This function is concerned with normalised headings derived from consideration of the intellectual construct we call the work and not with words found on or in physical objects.

For a better understanding of the second function, we need to grapple with the meaning of the term work-an immaterial, intellectual entity. Although a work is in reality always merged with a material vehicle, it is never confined to any particular vehicle, and may materialise at the same time in several different such vehicles. Its existence does not depend on any one of its manifestations.

While books are material and unchangeable entities with an a priori fixed form, a work may change, without losing its identity, or turning into a different, new work. Elemental objects, which are collocated by the second function, are linked each other because of the identity of the essence of their intellectual contents-they must almost share a common intellectual origin. Domanovszky considered it vital to provide a unique, unambiguous definition of the concept of work, and to characterise it clearly as a composite object of the second function.

The first and the second functions are distinct and autonomous. The first conveys information about separate items of the library on the basis of their physical characteristics, independently from the relationship which exists between intellectual component parts of these items, showing the library's holdings as a mass of distinct individual items. The second clarifies an essential relationship, rooted in the content of those items. Both functions deal equally with individual books, but the first function prefers the material aspect to intellectual one; the reverse is true of the second function.

III. The third function presents many analogies with the second-both are concerned with the immaterial content of their objects (works). There is a basic difference between the two functions-the component parts of the object of the third function are not connected with each other as are those of the second function. Domanovszky believed that the third function consisted in communicating information, in a normalised manner, about an author's oeuvre, i.e., about all the editions of all the works of a particular author in the collections of a library. The objects of this function are parts of manifestations of the author's oeuvre. Its task is to connect each separate unit of information in the catalogue about the author's oeuvre, so as to create new composite units of information, each one corresponding to the complete production of an author. In other words, Domanovszky defined the concept of edition as one of potential elemental objects that constitute the composite object-the work. Items collocated in this set of elemental objects must be linked each other by means of the headings derived from the core of their content. At very least they share the intellectual origin of their contents. Editions of a work can be defined as those items whose text is the original version or is an intellectually dependent version-such as a translation, an enlargement or an adaptation. 


\section{THE AUTHOR IN CATALOGUING}

Domanovszky paid special attention to the concept of authorship. He established an indissoluble and inalienable tie between work and author, and wanted the cataloguer to be always conscious of it. The names of authors appear on publications, but authorship relates to the work, not its manifestations, because it is based on the responsibility of the author for the creation and the composition of the intellectual or artistic content of the work. It is not sufficient to identify the author as one who put together (rather than created) the content of the work. Such a denotation would extend the concept authorship to include responsibilities that Domanovszky defined as "pseudo-intellectual," such as those of editors or compilers of a collection. Domanovszky preferred to define as author that person who wrote the original version of the work (or, by extension, who created the intellectual or artistic content). Such a formula means that later editions, translations, or revisions still remain part of the work, even if their form, structure, or text have been partly or completely created by someone else. Domanovszky believed that the work comprised the set of elemental objects (manifestations of that work) entered in the catalogue and linked to each other by the identity of the core of their contents. This implies, necessarily, that they must share the intellectual origin of their contents. ${ }^{16}$

\section{NOTES}

1. In the beginning of the 1990's, Diego Maltese and I started to translate Functions and Objects of Author and Title Cataloguing, in Italian which was later abandoned for many reasons. In that period, I succeeded in contacting by mail Maria, Domanovszky's wife, who lived in Budapest and gave me only a little information about his biography. Even the University Library of Budapest, contacted by mail, answered that they had no information. At the IFLA meetings in Copenhagen (1997) and in Amsterdam (1998) I met some Hungarian librarians (among whom was the Director of University Library of Budapest) whom I asked for information and from whom I got generic answers. In 1997 I assigned to Barbara Patui a thesis titled L'elaborazione catalografica di Ákos Domanovszky (Ákos Domanovszky's catalographical elaboration), presented at Università degli Studi di Udine, in the academic year 1998-1999. Meanwhile, Patui translated Functions and Objects of Author and Title Cataloguing, under revision at present, to be printed in 2001 by Forum, Udine. In the beginning of 2000 I started a correspondence with Agnes Hajdu Baratne, librarian and Professor of Library Science at Information Science Department of Budapest University. The following March, she sent me precious material, unavailable in Italy. Patui co-operated to this biographical profile, providing a translated version of Hungarian article by A cimleiro. Munkaja rossz lesz, ha csak a szabalyt tartja szem elott s nem egyuttal az. embert is, kinek szamara a cimeket leirja. Domanovszky Ákos emlékezete [The librarian. His work will not be perfect if he will consider only rules and not the man they are written for. In memory of Ákos Domanovszky] by Rózsa Gabriella Pogányné, published in <<Könyv, könyvtár, könyvtáros > in 1999, and other works, among which Fel évszázad az Egyetemi 
Könyvtárban. Beszélgetés Domanovszky Ákossal [Half of a Century in the Library of the University. An Interview with Ákos Domanovszky] by Vértesy Miklos, published in $<<$ Könyv, könyvtár, könyvtáros >> in 1977, which are fundamental to the first part of this work. Many thanks to Barbara and Agnes. Thanks also to Pino Buizza and Tiziana Pesenti who have read the manuscript. Thanks to Michael Gorman who has sent memories of his collegue (see note 9).

2. No heading for Domanovszky is in the two special issues of $<<$ Cataloging \& Classification Quarterly >> titled Portraits in Cataloging and Classification: Theorists, Educators, and Practitioners of the late Twentieth Century, Part I, vol. 25, nos. 2/3, $1998 \mathrm{e}$ part II, vol. 25, no. 4 (1998). No matches were found on the Internet.

3. R. G. Pogányné, A cimleire: munkaja rossz lesz, ha csak a szabalyt tartja szem elett $s$ nem egyuttal az embert is, kinek szamára a cimeket leirja. Domanovszky Ákos emlékezete, in <<Könyv, könyvtár, könyvtáros>>, 1999, p. 50-54.

4. Carlo Revelli was the first to introduce Domanovszky in Italy, reviewing Functions and Objects of Author and Title Cataloguing (Budapest, Akadémiai Kiadó, 1974) in $<<$ Bollettino d'informazioni $>>$ of the Italian Library Association, a. 17, n. 3, luglio-settembre 1977, pp. 246-248, in which it is possible to find echoes of already ended drafting of Regole italiane di catalogazione per autori. Later Alberto Petrucciani refers largely and critically to him in Funzione e struttura del catalogo per autore, Firenze, Giunta regionale toscana, La nuova Italia, 1984, pp. 45-48, passim, and also Alfredo Serrai in a note of his Storia della bibliografia. Vol. 7, Storia e critica della catalogazione bibliografica, Roma, Bulzoni, 1997, pp. 30-31, (note 4). Rossella Dini shares the objection of <<excessive pragmatism and of lack of theoretical fundaments, moved by Á. Domanovszky to M. Gorman's proposal at IMCE $>>$ and uses it as $<<$ pretext and starting point for her research $>>$ published in Il parente povero della catalogazione. La descrizione bibliografica dal Rapporto Henkle all'incontro di Copenaghen, Milano, Editrice Bibliografica, 1985; citation at p. 13.

5. $<<$ I know that Domanovszky lived from 1902 Oct. 28-1982 Apr. 9. This data is correct, I got this answer directly from the University Library in Budapest $\gg$. E-mail from Agnes Hajdu Baratnèè, 12 June 2000. Others refer 21 April.

6. Among librarians we can remember Józsefre Fitz, Tódos Miklósra Ász, Sándorra Kozocsa e Bélára Dezsényi.

7. Cf. V. Miklos, Fel évszázad az Egyetemi Könyvtárban: beszélgetés Domanovszky Ákossal., in <<Könyv, könyvtár, könyvtáros>>, 1977, p. 652; R. G. Pogányné, A cimleire: munkaja rossz lesz, ha csak a szabalyt tartja szem elett s nem egyuttal az embert is, kinek szamára a cimeket leirja. Domanovszky Ákos emlékezete, in $<<$ Könyv, könyvtár, könyvtáros>>, 1999, p. 50-54 and Á. DOMANOVSZKY, The new Hungarian draft code and the Paris statement of principles, in $<<$ International Cataloguing $>>$, vol. 1, no. 3, July-Sept. 1972, p. 3-4.

8. MAGYAR SZABVANYUGYI HIVATAL, Konyvtari cimieirasa szabalyok. 2. Hiadas. Budapest, 1958. Translated title: Cataloguing Rules for Libraries.

9. I asked Michael Gorman for a witness about their co-operation: $<<$ Caro Mauro, I have been trying to reclaim my memories of Domanovsky after all these years. He was a very dignified but kindly and supportive person (remember that I was very young ( 28 when I attended the IMCE in Kobnhavn in 1969-I will be 60 in three weeks)). I remember him saying that we should apply "engineering techniques" to bibliographic control-he wrote 
something to that effect about the syndetic structure of subject catalogues-and I think the orderly and structured approach of the ISBD appealed to him. His Hungarian colleagues-Prof. Sebastyen and Mrs Silvassy (I may have mis-spelled those names) were both very positive about my original report, done for Unesco, and that may have influenced his support of the ISBD. The discussions of the original ISBD group were focussed on how to translate my proposals (accepted by the IMCE) into a standard, the singular punctuation I proposed, and the level of detail of the standard. I was strongly in favour of the ISBD being a framework to be expanded by individual national codes and others wanted it to *be* an international code-the result was something of a compromise. When I think of the international reputations of the people on the original committee-Avram, Wells, Domanovsky, Verona, etc.-I am amazed that I, in my youth, was absolutely unafraid to put my own views forward!!! Molti saluti! Michael >> (from an E-mail from Michael Gorman, February 11, 2001).

10. MAGYAR SZABVANYUGYI HIVATAL, Konyvtari cimieirasa szabalyok, cit., passim.

11. $<<$ The principles established for treatment of works entered under title may be followed also in arranging entries under any particular author heading $>>$.

12. It is still to be analysed Domanovszky's opinion about AACR. An interesting reading is John A. Shinebourne's critical analysis of AACR: $<<$ This paper discusses some basic issues in cataloguing and offers a critique of AACR, very much influenced by the work of Ákos Domanovszky [note for Functions and Objects of Author and Title Cataloguing] and the work of Eva Verona [note for Literary Unit versus Bibliographical] >> and Michael Gorman's reply, who, matching critiques and bibliographical references, states that Shinebourne $<<$ has read little or understood little of recent writings on cataloguing $>>$ and declares $<<$ I yield to no one in my admiration for the work of Domanovszky, Verona, Lubetzky, and it grieves to me to see them misinterpreted, in what seems an attempt to attack AACR at any cost $>>$. In his answer, Shinebourne makes clearer Domanovszky's critiques to AACR: cfr. J. A. Shinebourne, A critique of AACR, in $<<$ Libri $>>$, vol. 29, no. 3, July-Sept. 1979, p. [231]-259; citation is at p. 231; M. Gorman, [Letter to] editors, in $<<$ Libri $>>$, vol. 30, no. 3, July-Sept. 1980, p. [247]-248; see citation at p. 248; J. A. Shinebourne, [Letter to] the editor, in <<Libri >>, vol. 30, no. 3, July-Sept. 1980, p. 249-250. Thanks to Pino Buizza for giving me this precious information.

13. This information has been confirmed in a letter of his wife and by Ágnes Hajdu Barátné, via e-mail on 13th June $2000<<$ The Functions and objects didn't publish in Hungarian, and they [University Library of Budapest] haven't any copies and manuscript. They have very few manuscript from him, because he correct and correct once again. I spoke with the "common" student, who is the deputy director in the University Library now $>>$, and in person on 26 October 2000, in Rome.

14. E. Verona, Literary unit versus bibliographical unit, in $<<$ Libri $>>$, Copenhagen, vol. 29, no. 2, Apr.-June 1959, p. 79-104. The essay has been published also in Foundations of Cataloging. A Sourcebook, edited by M. Carpenter and E. Svenonius, Littleton, CO, Libraries Unlimited, 1985, pp. 155-175.

15. Or in the chief source of information, with ISBD terminology.

16. It is still to be analysed the relationship between Domanovszky and FRBR; cfr. IFLA Study Group on the Functional Requirements for Bibliographic Records, Functional Requirements for Bibliographic Records: Final Report, approved by the Standing 
Committee of the IFLA Section on Cataloguing, München, Saur, 1998. See also: FRBR Seminar: Functional requirements for bibliographic records $=$ Requisiti funzionali per record bibliografici, Florence, 27th-28th January 2000: Proceedings, edited by Mauro Guerrini, Roma, Associazione italiana biblioteche, 2000.

\section{BIBLIOGRAPHIC REFERENCES}

\section{1. Ákos Domanovszky's Works}

Die korporative Verfasserschaft/Ákos Domanovszky.-p. 115-158.-Libri.-Copenhagen, vol. 11 (1961).

Der Code-Entwurf der Pariser Katalogisierungskonferenz/Ákos Domanovszky.p. 191-261.-Libri.-Copenhagen, vol. 12 (1962).

Digest of the comments received on "Bibliographical data in national bibliography entries" by Michael Gorman (DE2)/by Ákos Domanovzsky.-[1969].-(Working paper/IFLA International Meeting of Cataloguing Experts, Copenhagen, 1969; no. 2).-Cyclostyled.

The new Hungarian draft code and the Paris Statement of principles/by Ákos Domanovszky.-p. 3-4.-International cataloguing.-Vol. 1, no. 3 (July-Sept. 1972).

Editor entries and the principles of catologuing/Ákos Domanovszky.-p. 307-330.-Libri.-Copenhagen, vol. 23 (1973).

Functions and objects of author and title cataloguing: A contribution to cataloguing theory/by Ákos Domanovszky; English text edited by Anthony Thomson.-Budapest: Akadémiai Kiadó, 1974.

Functions and objects of author and title cataloguing: A contribution to cataloguing theory/by Ákos Domanovszky; English text edited by Anthony Thomson.-Munchen: Verlag Dokumentation, 1975.

Eine terminologische Bemerkung über die RAK/Ákos Domanovszky.-p. 311-320.Libri.-Copenhagen, vol. 29 (1979).

Editor entries and the principles of cataloguing/by Ákos Domanovszky.-p.192-206.-In: Foundations of cataloguing: A source-book/edited by Michael Carpenter and Elaine Svenonius.-Littleton, CO: Libraries Unlimited, 1985.

\section{Works About Ákos Domanovszky}

[Review] Domanovszky, Á. Functions and objects of author and title cataloguing. A contribution to cataloguing theory. Budapest, Akadémiai Kiadó, 1974/Carlo Revelli.p. 246-248.-Bollettino d'informazioni/Associazione italiana biblioteche.-Roma, n.s., a. 17, n. 3 (luglio-sett. 1977).

Fel évszázad az Egyetemi Könyvtárban: beszélgetés Domanovszky Ákossal/Vértesy Miklos.-p. 652-Könyv, könyvtár, könyvtáros.-Budapest, 1977.-Titolo tradotto: Mezzo secolo nella Biblioteca dell'Università: intervista a Ákos Domanovszky.

A cimleire: munkaja rossz lesz, ha csak a szabalyt tartja szem elett s nem egyuttal az embert is, kinek szamára a cimeket leirja. Domanovszky Ákos emlékezete/Rózsa Gabriella Pogányné.-p. 50-54.-Könyv, könyvtár, könyvtáros.-Budapest, Dec. 1999.

Interpreting the second objective of the catalog/Patrick Wilson.-p. 339-353.-Library Quarterly.-Chicago, vol. 59, n. 4 (1989). 


\section{Quick Reference Works}

Literary unit versus bibliographical unit/by Eva Verona.-p. 79-104.-Libri.-Copenhagen, vol. 29, no. 2 (1959).-The essay is republished in: Foundations of Cataloging: A Sourcebook, edited by Michael Carpenter and Elaine Svenonius.

Report/International conference on cataloguing principles, Paris, 9th-18th October, 1961; [edited by A.H. Chaplin and Dorothy Anderson].-London: International Federation of Library Associations, 1963.

Statement of principles: Adopted at the international conference on cataloguing principles, Paris, October 1961/annotated edition with commentary and examples by Eva Verona, assisted by Franz Georg Kaltwasser, P.R. Lewis, Roger Pierrot.-Definitive ed.-London: IFLA Committee on Cataloguing, 1971.

A critique of AACR/by J. A. Shinebourne.-p. [231]-259.-Libri.-Copenhagen, vol. 29, no. 3 (July-Sept. 1979).

[Letter to] editors/Michael Gorman.-p. [247]-248.-Libri.-Copenhagen, vol. 30, no. 3 (July-Sept. 1980).

[Letter to] the editor/John A. Shinebourne.-p. 249-250.-Libri.-Copenhagen, vol. 30, no. 3 (July-Sept. 1980).

A decade of IFLA's work on the standardization of bibliographic description/Eva Verona.-p. 216-233.-IFLA journal.-Vol. 6, no. 3 (1980).

Funzione e struttura del catalogo per autore/di Alberto Petrucciani.-Firenze: Giunta regionale toscana: La nuova Italia, 1984.

Il parente povero della catalogazione: la descrizione bibliografica dal Rapporto Henkle all'incontro di Copenaghen/Rosella Dini.-Milano: Editrice bibliografica, 1985.

La catalogazione dopo Parigi: attività normative e strumenti per il controllo bibliografico universale 1961-1997/Pino Buizza.-Udine: Forum, 1998.

Storia della bibliografia/Alfredo Serrai; a cura di Maria Cochetti.-Roma: Bulzoni, 1988- . -Vol. 7: Storia e critica della catalogazione bibliografica/a cura di Gabriella Miggiano.-c1997.

Functional requirements for bibliographic records: final report/IFLA Study Group on the Functional Requirements for Bibliographic Records; approved by the Standing Committee of the IFLA Section on Cataloguing.-München: Saur, 1998.

Seminario FRBR: Functional requirements for bibliographic records = Requisiti funzionali per record bibliografici, Firenze, 27-28 gennaio 2000: atti/a cura di Mauro Guerrini $=$ FRBR Seminar: Functional requirements for bibliographic records = Requisiti funzionali per record bibliografici, Florence, 27th-28th January 2000: proceedings/edited by Mauro Guerrini.-Roma: Associazione italiana biblioteche, 2000.

Introduzione a FRBR: Functional requirements for bibliographic records = Requisiti funzionali per record bibliografici/Mauro Guerrini.-Milano: Editrice bibliografica, 2001. 